\title{
Climate change impact on groundwater recharge and \\ suggested adaptation strategies for selected Asian cities
}

\begin{abstract}
Sangam Shrestha ${ }^{{ }^{*},}$, Ngoc Anh T. Hoang a , Pallav Kumar Shrestha ${ }^{\mathrm{b}}$, Binod Bhatta ${ }^{a}$
a Asian Institute of Technology, Kluang Luang, Pathumthani, 12120, Thailand

b Helmholtz Centre for Environmental Research, Permoserstraße 15, Leipzig, 04318, Germany

* Corresponding author. Email: sangam@ait.asia; Tel: +66-2524-60o5, Fax: +66-2524-6425
\end{abstract}

\section{ABSTRACT}

Currently, $54 \%$ of the world's population live in urban areas, and this figure is expected to increase to $66 \%$ by 2050 . Major cities and municipalities in the region rely either wholly or partially on groundwater. Four Asian cities, namely Bangkok, Bandung, Ho Chi Minh City, and Lahore, are selected for the study as their groundwater dependency is in the critical range of $45 \%$ to $100 \%$. Therefore, this study aims to assess current and future climate, quantify changes in climatic drivers, analyse the vulnerability of groundwater recharge systems to such changes, and then formulate adaptation strategies to reduce the vulnerability to groundwater resources in these cities. The methodology includes model-backed analysis of groundwater recharge vulnerability, which is later discussed with stakeholders (policymakers, scientists, and local water users) to prescribe possible adaptation options. The results show that Ho Chi Minh City and Bandung will receive less rainfall and Lahore and Bangkok more rainfall in the future. Bangkok is the only city in which minor fluctuations in future temperature is observed, while the remainder have significant increases (up to $3.1^{\circ} \mathrm{C}$ ). In line with the rainfall projections, Ho Chi Minh City and Bandung are projected to experience decreased groundwater recharge while the other two cities, Bangkok and Lahore are expected to have higher groundwater recharge in future.

\section{INTRODUCTION}

\subsection{Background}

Around two billion of the rural and urban population are using groundwater as the primary source of drinking water, accounting for roughly $32 \%$ of the total drinking water supply (Morris et al., 2003). Currently, $54 \%$ of the world's population live in urban areas, and this figure is expected to increase to $66 \%$ by 2050 . Projections show that urbanization, combined with overall global growth could add another 2.5 billion people to the urban population by 2050 , with close to $90 \%$ of such increase concentrated in Asia and Africa. Major cities and municipalities in the region rely either fully or partially on groundwater as a part of the water supply network, where it is also used by small-scale rural or town water supply systems. For example, groundwater dependency is $70 \%$ for domestic and $60 \%$ for industrial water demand in Bandung, Indonesia (2007 estimate; Tirtomihardjo, 2015), 45\% in HCMC, Vietnam (2012 estimate;

\section{KEYWORDS}

Groundwater, Climate change, Bangkok, Bandung, Ho Chi Minh City, Lahore

DOI

https://doi.org/10.30852/sb.2018.499

\section{DATES}

Received: 11 January 2018

Published (online): 29 November 2018

Published (PDF): 17 December 2018

\section{HIGHLIGHTS}

» The future climate of four Asian cities: Bangkok, Bandung, Ho Chi Minh City (HCMC), and Lahore were projected using multiclimate models

» A water balance/hydrological model was developed to simulate groundwater recharge in four Asian cities

» Future temperature is projected to increase in all four cities in accordance with global trends

» Rainfall in HCMC and Bandung is projected to decrease, whereas it is projected to increase in Bangkok and Lahore

» In line with the rainfall patterns, groundwater recharge is expected to decrease in HCMC and Bandung, while projected to increase in Bangkok and Lahore 


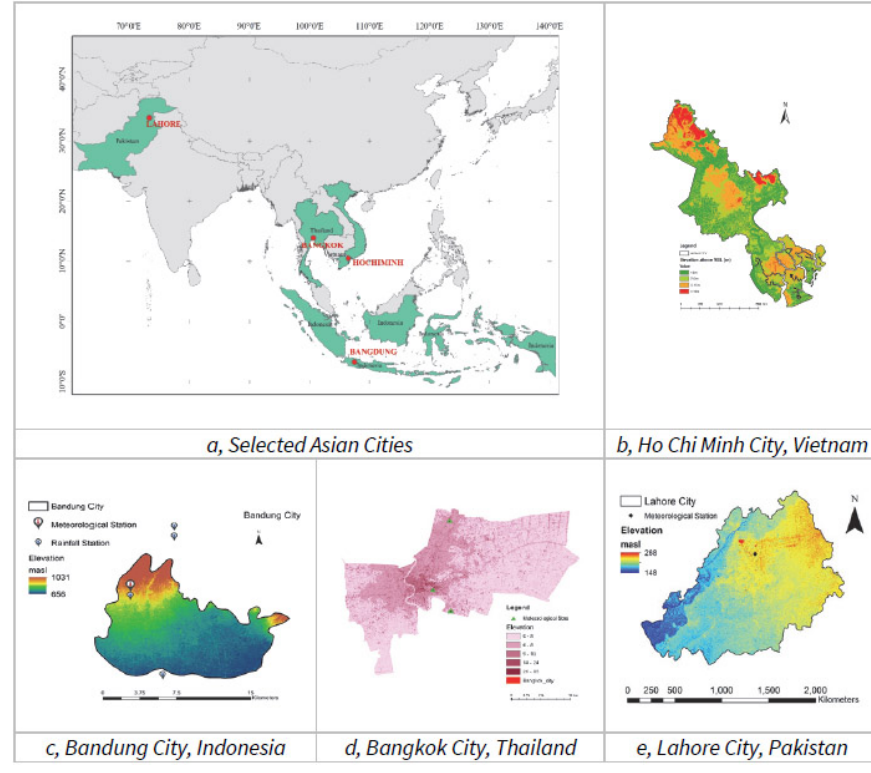

FIGURE 1. Location of selected Asian cities: Bangkok, Bandung, Ho Chi Minh City, and Lahore

Vuong, Long, \& Nam, 2015) and 100\% in Lahore, Pakistan (Basharat, 2015). Despite the significance of groundwater for sustainable development, it has not always been adequately managed, often resulting in depletion and degradation of the resource. Due to various pollution sources and climate change in urban areas, the quality and quantity of groundwater have become critical issues for urban groundwater environments (Collin \& Melloul, 2003). The strategic importance of groundwater for global water and food security will probably intensify under climate change as more frequent and intense climate extremes (droughts and floods) increase variability in precipitation, soil moisture, and surface water (Taylor et al., 2013). The predicted impact of climate warming on groundwater include changes in the magnitude and timing of recharge (Hiscock et al., 2012), typically with a shift in seasonal mean and annual groundwater levels depending on changes in the distribution of rainfall (Liu, 2011) and snowmelt (Jyrkama \& Sykes, 2007; Okkonen \& Kløve, 2010). The predicted changes in recharge may be more significant than for precipitation (Ng, McLaughlin, Entekhabi, \& Scanlon, 2010).

The purpose of this study is to assess the current and future climate, quantify changes in climatic drivers, analyse vulnerability of groundwater recharge systems to such changes, and then formulate adaptation strategies to reduce the vulnerability of groundwater resources in selected Asian cities, namely Bangkok, Bandung, HCMC, and Lahore, through the collaborative effort of scientists, policymakers, and relevant stakeholders.

The selected Asian cities are highly dependent on groundwater since it is the major source of drinking water, and water for industrial and other commercial

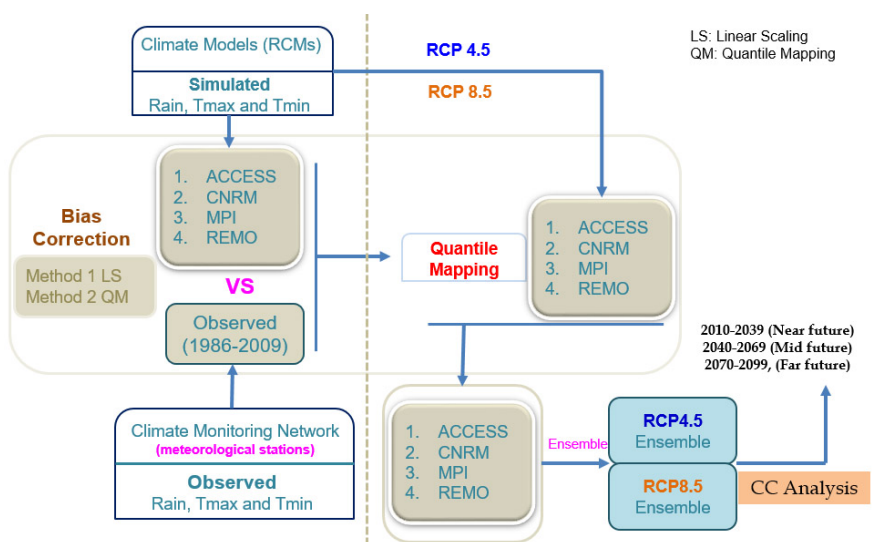

FIGURE 2. Future climate projection methodology adopted in this study

uses. The groundwater dependency of these selected cities ranges from $45 \%$ to $100 \%$, and thus, assessment of groundwater vulnerability in the context of a changing climate is essential for sustainable groundwater management.

\subsection{Objectives}

The overall objective of this study is to assess the climate change impact on groundwater recharge and formulate adaptation strategies in four selected Asian cities. Specific objectives are to:

" assess the current and future climate and related trends in the selected Asian cities;

» assess the vulnerability of groundwater recharge systems to climatic change in those cities; and

" formulate adaptation strategies for reducing the vulnerability of groundwater recharge to climate change.

\section{METHODOLOGY}

\subsection{Study Areas}

The selected four fast-growing cities in Asia consist of Bangkok, HCMC, Bandung, and Lahore (Figure 1). Addressing water shortage problems and pressure on groundwater use requires greater attention and decisive action in these cities. Not only is the increase in water demand posing stress on groundwater use but the adverse impact of climate change is also apparently taking place, resulting in groundwater depletion and groundwater-related problems. Understanding the impact of future climate on groundwater resources would facilitate effective water management in the four cities. This examines the physical science relating to climate change and hydrology using multiple modelling approaches. The four cities were selected for this research on the basis of their groundwater dependence, which ranges from 45 to $100 \%$. 


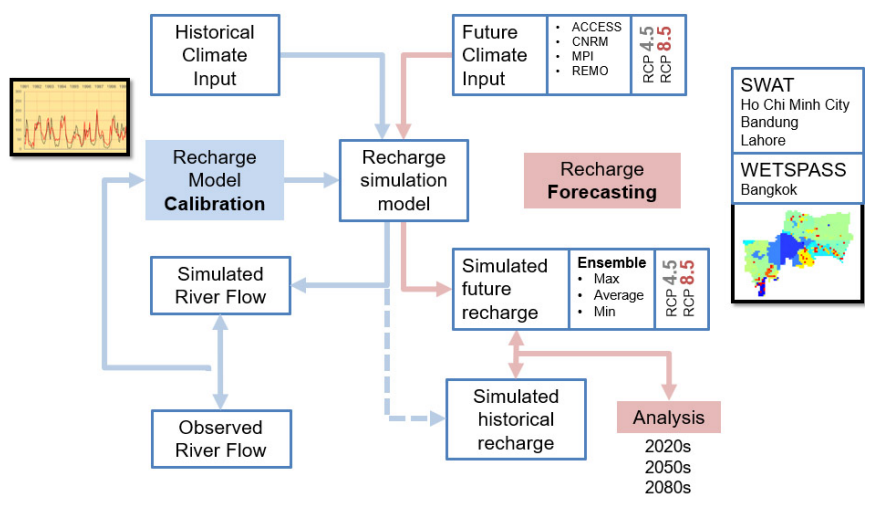

FIGURE 3. Method for simulating groundwater recharge in the four cities

Bandung is the capital of the West Java Province in Indonesia. It is the nation's third most populous city, with over 2.6 million people (2015). The city lies on a river basin surrounded by volcanic mountains. As a rapidly developing metropolitan region, the Bandung Basin is experiencing increasing problems with groundwater, with an imbalance between discharge and recharge. The groundwater levels have dropped by more than 50 metres from their original level, forming a cone of depression in the water table and creating a critical zone, especially in industrial areas.

HCMC is the economic capital of Vietnam. It is situated in a transition zone stretching from the hilly areas in the middle of Vietnam to the lowlands of the Mekong Delta. HCMC is enclosed by Tay Ninh and Binh Duong Provinces in the north, Dong Nai, and Ba Ria-Vung Tau Provinces in the east, and Long An Province in the west. The southern part of HCMC is bounded by the East Sea with a 30 $\mathrm{km}$ stretch of coastline. The city covers an area of 2095 $\mathrm{km}^{2}$, extended in the northwest to southeast direction, with a maximum length of $100 \mathrm{~km}$ and a maximum width of $45 \mathrm{~km}$. It is crisscrossed by the canals and tributaries of the Dong Nai-Sai Gon River system with an elevation decreasing from north to south. Most of the city area has a low elevation from 0 to $2 \mathrm{~m}$ above MSL as shown in Figure 1. HCMC is currently the most important economic centre of Vietnam. In 2012, its GDP was around 30 billion USD, making up $21.7 \%$ of the total national GDP (Shrestha, Pandey, Thatikonda, \& Shivakoti, 2016). The present population of the city is 7.7 million, which has increased rapidly with a growing net emigration rate as well as increased urbanization, construction activities, and groundwater use. HCMC has a total of 257,216 wells with an extraction rate of $717,246 \mathrm{~m}^{3} / \mathrm{d}$.

Lahore is the capital of Punjab Province in Pakistan. It is the nation's second most populous city, with over 11 million people (Basharat, 2015). The city lies on a river basin surrounded by agricultural lands and other relatively less crowded cities. As a rapidly developing metro-

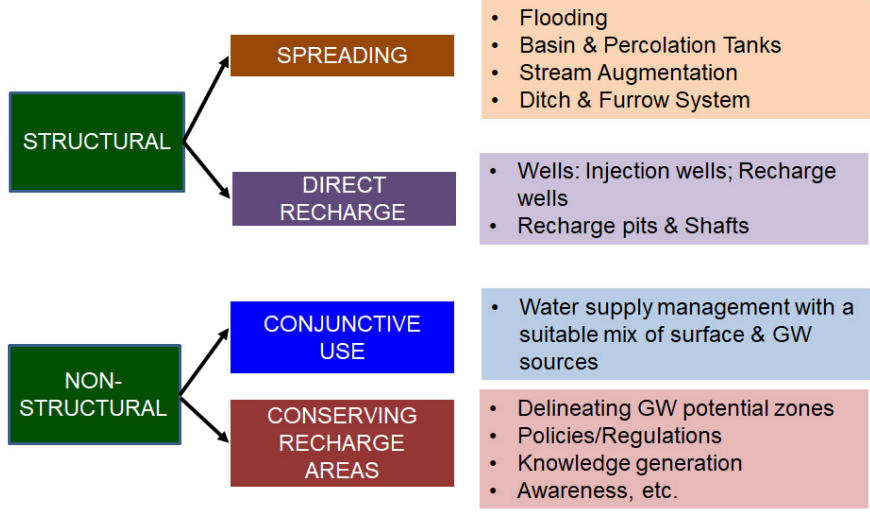

FIGURE 4. Potential adaptation options identified from a literature review

politan region, Lahore is experiencing growing problems with groundwater due to an imbalance between discharge and recharge. The groundwater levels have dropped at an annual rate of 0.45 to $1.50 \mathrm{~m}$; more than $45 \mathrm{~m}$ from their original level, forming a cone of depression in the water table and expanding the critical zone.

Bangkok is the capital of Thailand and the most populated city in the country. The city is home to more than $13 \%$ of the country's population, and the hub for most of the commercial and economic activities in the kingdom. At the same time, the city is very popular with visitors and appreciated for its versatility and multiple points of interest. The economy of Thailand has been rising dramatically over the past 50 years to which Bangkok has made a significant contribution. The city of Bangkok is in the southern part of Thailand and occupies a total area of $1570 \mathrm{~km}^{2}$.

\subsection{Methods and Data}

The methodology used to assess the climate change impact on groundwater recharge consists of three parts: (1) climate change analysis (CCA) for projecting the future climate of the cities; (2) groundwater recharge modelling based on future climate projections; and (3) the adaptation option. The methodology for CCA is shown in Figure 2, while Figure 3 shows the methodology to simulate groundwater recharge in the four cities. Adaptation options were identified following the flowchart presented in Figure 4.

The data used for the study was collected from various sources, consisting of hydrological, meteorological, soil type, and land use/land cover. Future climate data was obtained from four Regional Climate Models (RCMs) under Representative Concentration Pathways (RCP) 4.5 and 8.5. The RCP8.5 represents a rising radioactive forcing pathway leading to $8.5 \mathrm{~W} / \mathrm{m}^{2}(\sim 1370 \mathrm{ppm}$ CO2 equivalent by 2100) (Riahi et al., 2011). RCP6.0 represents stabilization after 2100 without overshooting the 


\begin{tabular}{|l|l|l|l|l|l|}
\hline RCM & Parent GCM & $\begin{array}{l}\text { Resolution } \\
\text { (degree) }\end{array}$ & Hindcast & Forecast & Developer \\
\hline CCAM & ACCESS1.0 & 0.5 & $1970-2005$ & $2006-2099$ & Australian Bureau of Meteorology, Australia \\
\hline CCAM & CNRM-CM5 & 0.5 & $1970-2005$ & $2006-2099$ & National center for Meteorological Research, France \\
\hline RCA4 & MPI-ESM-LR & 0.5 & $1970-2005$ & $2006-2099$ & Max-Planck-Institute for Meteorology, Germany \\
\hline REMO 2009 & MPI-ESM-LR & 0.5 & $1970-2005$ & $2006-2099$ & Climate Service Center, Germany \\
\hline
\end{tabular}

TABLE 1: Four selected RCMs for the study and their properties

pathway to $6 \mathrm{~W} / \mathrm{m}^{2}$ ( $\sim 850 \mathrm{ppm}$ CO2 equivalent) (Masui et al., 2011). The RCP4.5 gives stabilization without overshooting the pathway to $4.5 \mathrm{~W} / \mathrm{m}^{2}(\sim 650 \mathrm{ppm} \mathrm{CO} 2$ equivalent) after 2100 (van Vuuren et al., 2011). The RCMs were selected based on experience and the literature review. Since three out of the four cities are in Southeast Asia, the researchers selected climate model results proven as being better suited for CCA studies in the region by McSweeney, Jones, Lee, and Rowell (2015). Out of the 28 GCMs evaluated, they found ACCESS 1-0, CNRM-CM5, and MPI-ESM-LR to be among the "satisfactory" performing models in South East Asia. Brief information on the selected models is provided in Table 1.

The hydrological models, Soil and Water Assessment Tool (SWAT), and Water and Energy Transfer between Soil, Plants and Atmosphere under Steady State condition (WetSpass) were used to estimate the groundwater recharge in this study. The SWAT is a semi-distributed hydrological model, which forms a hydrological domain (Arnold, Srinivasan, Muttiah, \& Williams, 1998). SWAT was applied to Lahore, HCMC, and Bandung cities. In the case of Bangkok, it was difficult to cover the city within a hydrological catchment and thus the WetSpass model was used instead. WetSpass is a physically based model for estimating the spatial variations of groundwater recharge, surface run-off, and evapotranspiration. WetSpass uses a cell by cell water balance approach and thus does not require the model domain to be a hydrological catchment (Batelaan and De Smedt, 2001).

Both models were calibrated and validated in the respective cities. The SWAT consists of numerous parameters that govern the response of the model. These parameters are process-based and must be within a realistic uncertainty range (Arnold et al., 2012). Sensitivity analysis was performed to determine the most sensitive parameters for a given watershed. Sensitivity analysis of the catchments was performed using the SWAT-CUP (SWAT Calibration and Uncertainty Programs) tool. The sensitive parameters were then used to calibrate the model against the observed discharge data. Auto-calibration was then performed using SWAT-CUP followed by fine-tuning via manual calibration. Model validation was conducted to ensure that the model would be capable of accurate simulation using new sets of input data. Based on this hydrological calibration of the model, it was concurred that the spatially varied recharge output could also be validated. The efficiency of the model (NSE and $\mathrm{R}^{2}$ ) was greater than 0.5 and hence considered to be satisfactory.

In the case of WetSpass, the initial groundwater levels were interpolated at each cell from the groundwater measurement stations to initialize the model. After model calibration, future bias- corrected climate data was input to obtain future groundwater recharge projections. Altogether there were eight probabilities for future groundwater recharge from four RCMs and two RCP scenarios. An ensemble (average) between the RCMs was considered to be the representative projection for each RCP4.5 and RCP8.5.

\section{RESULTS AND DISCUSSION}

\subsection{Annual Rainfall Trends}

Annual rainfall trends are presented in Figure 5. Each graph is divided into four frames, with the historical period 1978-2005 as the baseline in the first frame. The future period depicted on the right-hand side is broken down into three periods; the 20s (2006-2040), 50 s (2040-2070), and 80s (2070-2100).

The combined graph in Figure 6 presents the changes in annual rainfall pattern for the four cities during the twenty-first century under RCP4.5 and RCP8.5. The precipitation prediction for the future period was compared with the past of 1978-2005. In general, future rainfall in Lahore and HCMC is projected to follow an upward trend, while in Bandung and Bangkok it is predicted to decrease.

For Bandung, HCMC, and Lahore the past trend shows decreased rainfall in recent years, while in con-

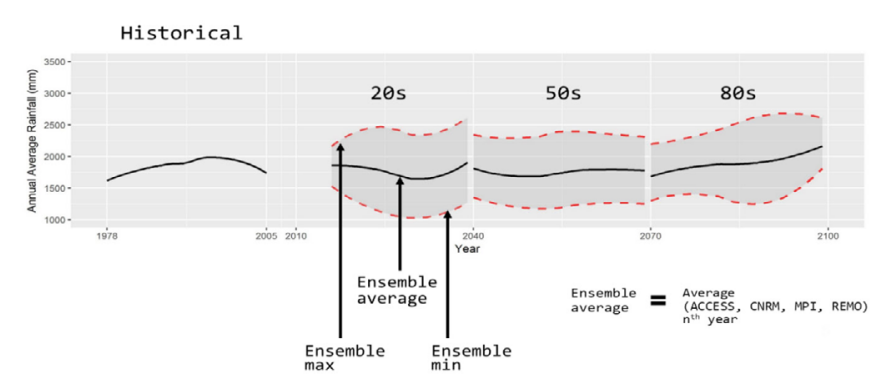

FIGURE 5. Annual rainfall graph components 


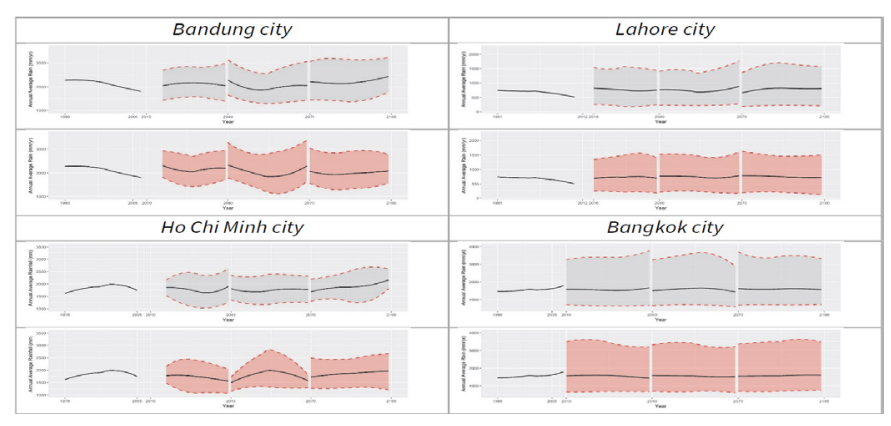

FIGURE 6. Annual future rainfall patterns for Bandung, HCMC, Bangkok, and Lahore. Grey - RCP4.5, Red - RCP8.5

trast, Bangkok shows a gradual rise in historical rainfall. Compared to the baseline period, the Bandung RCP4.5 ensemble (average) projects a slight decrease overall with an increase in the $80 \mathrm{~s}$, and for RCP8.5 there is an overall decrease with the average plunging below 2000 $\mathrm{mm}$ per year. As with Bandung, the future precipitation pattern of Bangkok will slightly decrease under both RCP4.5 and RCP8.5.

It is predicted that for the near future, by 2040 the rainfall might continuously decrease in HCMC. Under RCP4.5 scenario, the future rainfall showed a slight downward trend overall with some increment from the 2080s, while the predicted rainfall under RCP8.5 varied considerably. Up to 2070, HCMC might face drier years, after which the rainfall could start to increase again.

For Lahore, the past trend shows decreased rainfall in recent years. Compared to the year 2005, RCP4.5 projects a slight increase overall, with a variation in the $50 \mathrm{~s}$ and 80 s. While under RCP8.5 there is an overall increase throughout the twenty-first century with a slight decrease in the 80s. Detailed monthly rainfall trends and a summary of percentage changes for the future period relative to the baseline are presented in Figure 7.

In summary, Bandung future climate projections show that the rainfall is going to decrease in the dry season and increase slightly in the wet. However, the overall decrease is negligible for RCP 4.5 and $-3.5 \%$ for RCP 8.5. Similarly, future rainfall in HCMC might follow a downward trend. Projections show that the amount of rainfall is going to decrease in both the dry and wet seasons, by varying degrees under RCP8.5 $(-4.2 \%)$ and RCP4.5 (-3.3\%).

In contrast, Lahore future climate projections indicate that rainfall is going to increase significantly in the dry season and slightly in the wet. Average rainfall is likely to increase by 11 to $14.5 \%$ during the twenty-first century under RCP4.5 and RCP8.5, respectively. For Bangkok, the average annual rainfall is going to increase in all periods under RCP8.5, except the 2050 s. The projected rainfall during the dry season under both RCP scenarios is going to increase; however, during the wet season, it is predicted to increase under RCP4.5 and decrease under RCP8.5.

\subsection{Temperature Trends}

The temperature in all four cities is projected to increase in line with future global temperature trends. The maximum and minimum temperatures in the selected cities are presented in Figure 8.

Maximum temperature trends for Bandung are showing increasing trends in recent years. According to RCP4.5, there will be an overall increase of $1{ }^{\circ} \mathrm{C}$ by the end of the century, with a plateau in the 80 s (compared to the 2005 value). Whereas, for RCP8.5, the overall increase will be almost $3^{\circ} \mathrm{C}$ by the end of the century, with continually increasing trends over the 20s, 50s, and 80 s (compared to the 2005 value).

For HCMC, an upward trend in maximum temperature is indicated under both RCP4.5 and RCP8.5 compared to the historical period (1978-2005). The RCP4.5 predicted that the maximum temperature would rise by $1^{\circ} \mathrm{C}$ by the end of the century, and by almost $2.5^{\circ} \mathrm{C}$ under RCP8.5, with continuously increasing trends over the 20s, 50s, and 80s.

The historical trend of maximum temperature for Lahore shows mixed patterns of decreasing and increasing trends, which are set to continue in the coming years. There will be an overall increase in maximum temperature of 1.5 and $4.5^{\circ} \mathrm{C}$ by the end of the century for RCP 4.5 and RCP8.5, respectively. Maximum temperature shows possible variations in the 50 s for RCP4.5. However, for RCP8.5 a consistent increase until the end of the twenty-first century is observed.

For Bangkok, the baseline period presents an increasing trend in recent years of $0.02{ }^{\circ} \mathrm{C} /$ year. According to RCP4.5, there will be increases of between 0.42 and $1.01{ }^{\circ} \mathrm{C}$ during the 50 and 80 s period, respectively and an overall decrease of $0.14^{\circ} \mathrm{C}$ during the 20s [compared to the baseline value of $33.28{ }^{\circ} \mathrm{C}$ ]. Whereas, for RCP8.5, the overall increase will be $0.34,0.37$, and $1.77^{\circ} \mathrm{C}$ during the 20s, 50s, and 80s, respectively. Consequently, a constantly increasing trend can be observed in maximum temperature over the $20 \mathrm{~s}, 50 \mathrm{~s}$, and $80 \mathrm{~s}$.

A summary of the comparative change in average annual rainfall and average annual maximum and minimum temperatures under RCP4.5 and RCP8.5 for the four cities is presented in Table 2 . The change in projected climate varies between the four project cities. Regarding rainfall, HCMC is going to see a greater decrease than in the past of around 3 to $4 \%$. Bandung is also projected to receive less rainfall, especially according to the RCP 8.5 scenario. Whereas, Bangkok and to a greater extent Lahore, are expected to receive a boost in annual precip- 


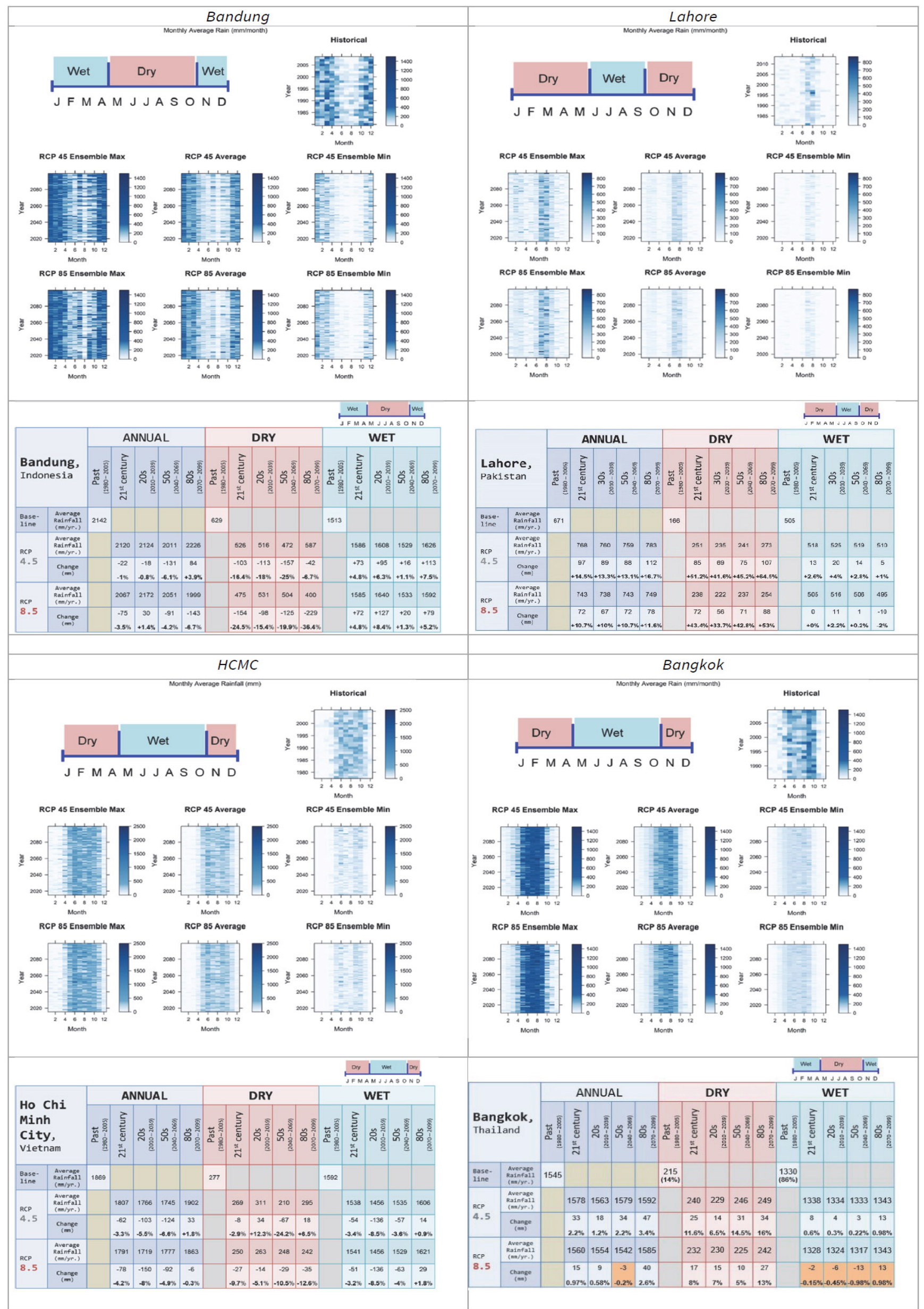

FIGURE 7. Monthly future rainfall and summary of percentage change in annual, dry, and wet season rainfall for Bandung, HCMC, Bangkok, and Lahore 


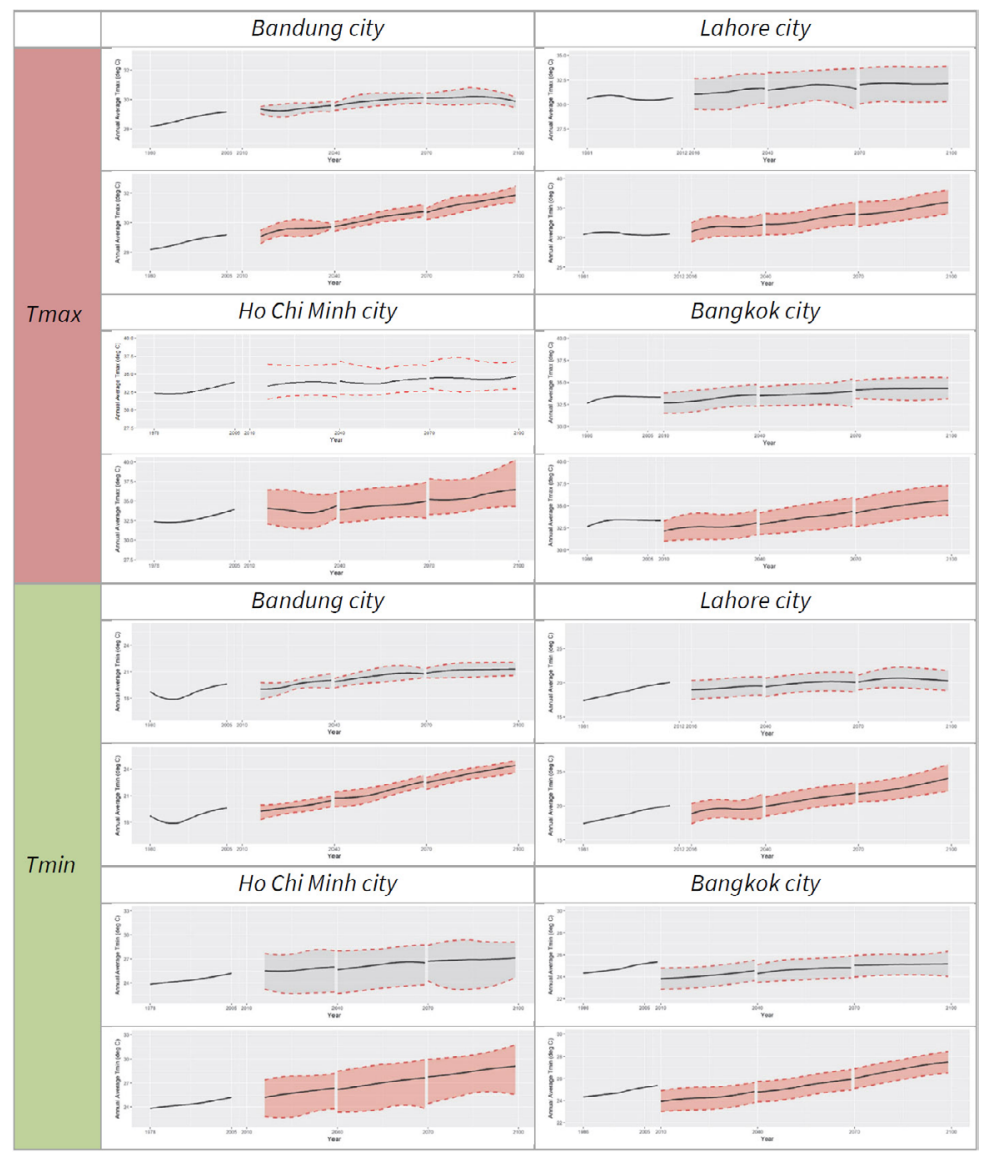

FIGURE 8. Annual temperature trends for Bandung, HCMC, Bangkok, and Lahore

\begin{tabular}{|c|c|c|c|c|c|}
\hline \multirow{2}{*}{\multicolumn{2}{|c|}{$\begin{array}{l}\text { Climate Change Projections } \\
\text { in the } 21^{\text {st }} \text { century }\end{array}$}} & \multicolumn{4}{|c|}{ Project Cities } \\
\hline & & \multirow{2}{*}{$\begin{array}{l}\text { Bandung } \\
-1.0 \%\end{array}$} & \multirow{2}{*}{$\begin{array}{l}\text { Lahore } \\
+14.5 \%\end{array}$} & \multirow{2}{*}{$\begin{array}{c}\text { Ho Chi } \\
\text { Minh }\end{array}$} & \multirow{2}{*}{$\begin{array}{l}\text { Bangkok } \\
+2.2 \%\end{array}$} \\
\hline Rainf & RCP 4.5 & & & & \\
\hline$\%$ against & $\mathrm{RCP} 8.5$ & $-3.5 \%$ & $+10.7 \%$ & $-4.2 \%$ & $+0.97 \%$ \\
\hline Maximum & $\mathrm{RCP} 4.5$ & +1.1 & +1.2 & +1.2 & +0.43 \\
\hline Degree C & $\mathrm{RCP} 8.5$ & +1.7 & +2.6 & +1.7 & +0.47 \\
\hline Minir & $\mathrm{RCP} 4.5$ & +1.9 & +1.1 & +1.9 & -0.16 \\
\hline Degree C & RCP 8.5 & +3.1 & +2.2 & +2.6 & +0.7 \\
\hline
\end{tabular}

TABLE 2. Climate change projection for the four cities

\begin{tabular}{|c|c|c|c|c|c|}
\hline \multirow{2}{*}{$\begin{array}{l}\text { GW Recharge Projections } \\
\text { in the } 21^{\text {st }} \begin{array}{l}\text { century } \\
\text { \% against baseline }\end{array}\end{array}$} & \multicolumn{4}{|c|}{ Project Cities } \\
\cline { 2 - 6 } & RCP 4.5 & $-2.9 \%$ & $+82.9 \%$ & $-13.8 \%$ & $+111 \%$ \\
\cline { 2 - 6 } Annual & RCP 8.5 & $-10 \%$ & $+74.1 \%$ & $-14.4 \%$ & $+120 \%$ \\
\hline \multirow{2}{*}{ Dry Season } & RCP 4.5 & $-8.2 \%$ & $+99.0 \%$ & $-33.2 \%$ & $+84.6 \%$ \\
\cline { 2 - 6 } & RCP 8.5 & $-14.7 \%$ & $+87.3 \%$ & $-38.5 \%$ & $+101 \%$ \\
\hline \multirow{2}{*}{ Wet Season } & RCP 4.5 & $+2.0 \%$ & $+62.3 \%$ & $-4.0 \%$ & $+147 \%$ \\
\cline { 2 - 6 } & RCP 8.5 & $-5.6 \%$ & $+57.0 \%$ & $-2.2 \%$ & $+147 \%$ \\
\hline
\end{tabular}

TABLE 3. Groundwater recharge projections for selected Asian cities itation, with the former having an increase in rainfall of +10 to $+14.5 \%$ and the latter up to $+2.2 \%$.

As for temperature, Bangkok is observed to experience the least fluctuation from the baseline during the twenty-first century. Whereas, the three other cities are all expected to receive an increase in temperature in the range of +1.1 to $+3.1{ }^{\circ} \mathrm{C}$. However, minimum temperature was observed to be more affected by climate change compared to the maximum daily temperatures.

\subsection{Groundwater Recharge Trends}

The spatial and temporal variation in future groundwater recharge is presented in Figure 9. A greater variability in groundwater recharge is expected for all cities in the future. The groundwater recharge in Bandung is projected to decrease by $-2.9 \%$ and $-10.0 \%$ based on RCP4.5 and RCP8.5, respectively. The larger proportion of the decrease is seen in the dry season with a -8.2 and $-14.7 \%$ decrease in comparison to +2 and $-5.6 \%$ fluctuations during the wet season for RCP4.5 and RCP8.5, respectively.

For Lahore, groundwater recharge is projected to increase by 82.9 and $74.1 \%$ based on RCP 4.5 and RCP 8.5 , respectively. The proportional increase is larger during the dry season at 99 and $87.3 \%$, compared to 62.3 and
$57 \%$ in the wet season for RCP4.5 and RCP8.5, respectively.

For HCMC, groundwater recharge is projected to decrease by -13.8 and $-14.4 \%$ based on RCP 4.5 and RCP8.5, respectively. The proportional decrease is larger in the dry season at -33.2 and $-38.5 \%$ compared to -4 and $-2 \%$ in the wet season for RCP 4.5 and RCP8.5, respectively.

The groundwater recharge for Bangkok is projected to increase by 111 and $120 \%$ based on RCP 4.5 and RCP8.5, respectively. The proportional increase is larger in the wet season at 154 and $162 \%$ under RCP 4.5 and RCP8.5, respectively. Recharge during the dry season also shows a positive change, although to a lesser extent than in the wet season.

A summary of the changes in future groundwater recharge under RCP4.5 and RCP8.5 for the four cities is presented in Table 3. Climate model input based on the modelling of groundwater recharge projection shows different results for the four cities. On the one hand, Bandung and HCMC are both projected to have declining groundwater recharge in the upcoming decades. While on the other hand, Bangkok and Lahore are expected to receive a considerable increase in groundwater recharge. This is in line with the projected changes in rainfall for the four cities. However, in the case of Bangkok, the 


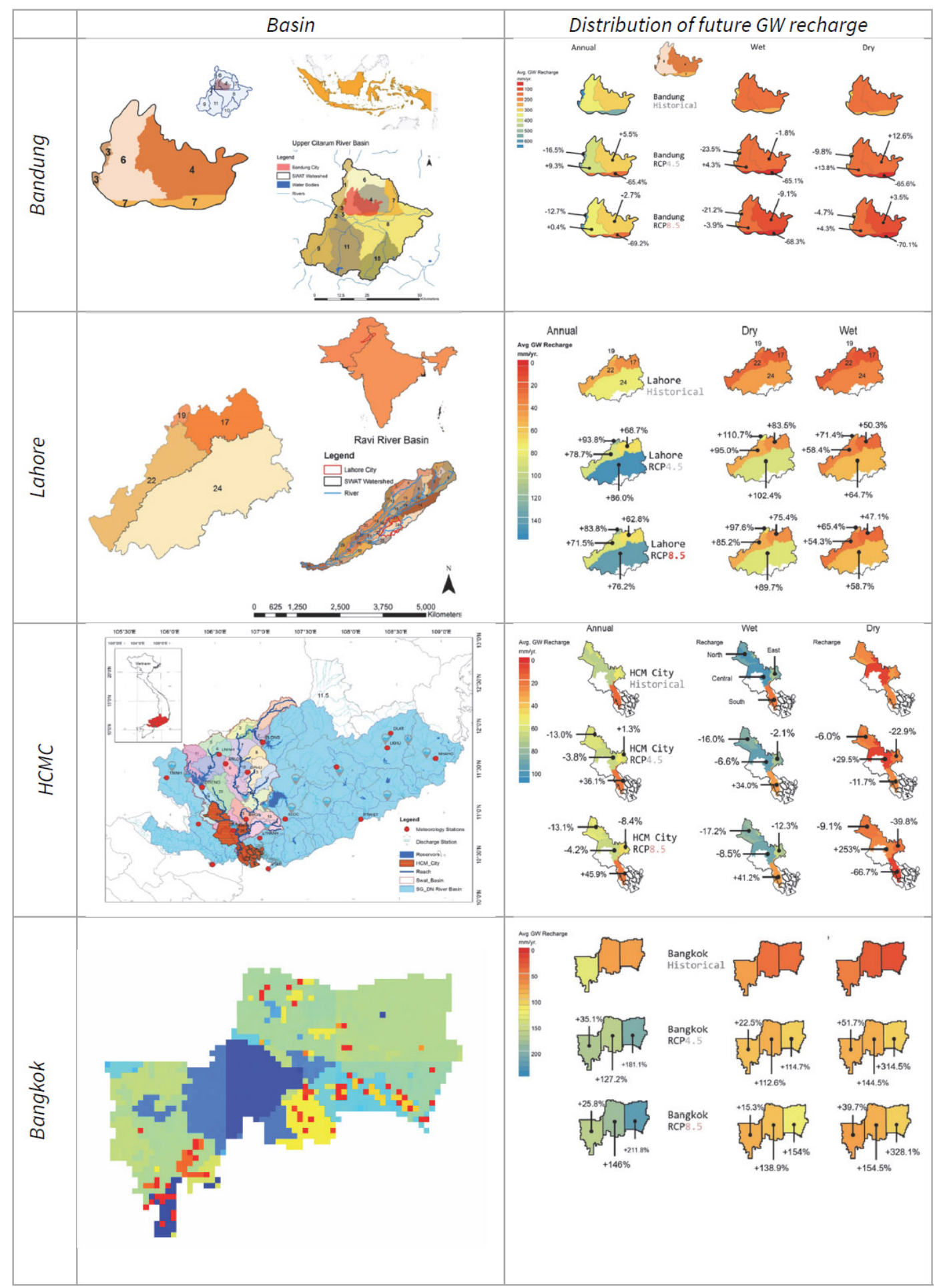

FIGURE 9. Groundwater recharge model domain and distribution of future groundwater recharge for Bandung, HCMC, Bangkok, and Lahore

minimal changes in temperature seem to have played a prominent role in simulating a substantial groundwater recharge increase in the future compared to the baseline.

For Bandung and HCMC, the decrease in groundwater recharge is more severe in the dry season with the latter projected to suffer as much as a $-38.5 \%$ decrease in recharge rates. In the case of Lahore and Bangkok, the rate of recharge increase is higher in the dry season for the former and lower for the latter.

\subsection{Adaptation Options}

A group discussion was organized on 8 and 9 September 2017 at the Asian Institute of Technology (AIT) to identify potential adaptation options for reducing the vulnerability of groundwater to climate change in each city. The participants included those involved in the project from each of the cities under study and invited groundwater experts. During the workshop, a detailed 
report on projected changes in climatic variables and the subsequent impact on groundwater recharge obtained from the model-based study was presented before the group discussion. Based on the typical characteristics of participating cities, suitable adaptation options were then identified and prioritized as discussed below:

\section{Bandung City}

In general, groundwater recharge (annual and seasonal values) for Bandung is projected to decrease. The following adaptation options are expected to be useful in dealing with climate change impact on groundwater resources:

» Estimate safe yields and potential groundwater critical zones for adoption in groundwater planning and regulations

»Conjunctive use of surface and groundwater sources

» Stream augmentation using constructed check dams

» Integrate the recharge agenda with the flood control agenda and vice-versa

» Strengthen groundwater monitoring networks

"Arrange regulatory provision for groundwater abstraction

» Address mainstream groundwater issues or other similar city-wide initiatives in resilient cities

Lahore

Projected recharge in the Lahore aquifer is expected to increase in both the near and far future. However, the soil is predominantly loam and, therefore, strategies for enhancing recharge on a larger scale may be less useful. In this context, Lahore needs strategies to regulate groundwater abstraction. The following adaptation options, in decreasing order of priority, are identified:

» Direct recharge using recharge wells (same as the abstraction well) fed by rainwater harvesting

"Augment river flow by constructing check dams

" Enhance agricultural return flow by increasing irrigation intensity (water allocation)

» Regulate groundwater abstraction from groundwater depression zones and combine with rainwater harvesting techniques and conjunctive water use or re-use of water

» Identify potential groundwater recharge zones and formulate regulations for their protection

» Establish a groundwater level monitoring mechanism for both networks and institutions

" Address mainstream groundwater issues or other similar city-wide initiatives in resilient cities
HCMC

The following three problems in relation to groundwater in HCMC were identified during the second regional workshop: i) groundwater is being depleted for various reasons, and different locations may experience varying degrees of depletion in the future; ii) saline water intrusion, and iii) land subsidence. The following adaptation options are identified and listed in order of decreasing priority to address the issue of groundwater depletion:

»Calculate safe yield complying with existing regulations for current and future time periods

» Identify areas experiencing greater groundwater depletion for current and future conditions

» Integrate recharge agenda with flood control agenda and vice-versa

» Install bank infiltration structures at suitable locations

» Move the well-field towards the northern part of the city

\section{Bangkok}

Groundwater management in Bangkok is already at an advanced stage compared to other cities. The Groundwater Act has been in place for some time and includes financial instrument provisions. Critical zones for groundwater abstraction are already identified. A project for artificial recharge along the Chao Phraya River is also in place. Therefore, adaptation strategies are slightly different to those in the other cities. The adaptation options identified during the second regional workshop are listed hereunder in decreasing order of priority:

» Regulatory mechanisms for increasing groundwater abstraction in the areas of rising groundwater levels to keep them within a safe depth

» Increase stakeholder awareness on rising groundwater levels at the post-regulation stage

»Evaluate/update safe yield at regular intervals to maintain the groundwater level at a particular depth

» Address mainstream groundwater issues or other similar city-wide initiatives in resilient cities

\section{CONCLUSIONS}

Groundwater is very important to the sustainable development of many Asian cities. In addition to rapid population growth, urbanization, and pollution, climate change is an emerging challenge to groundwater development and management. Therefore, the aim of this study was to investigate the impact of climate change on groundwater recharge and identify adaptation options in four Asian cities namely, Bangkok in Thailand, Bandung in Indonesia, HCMC in Vietnam, and Lahore in Pakistan. 
An integrated approach was used to conduct this study. Firstly, climate change in the cities was projected using four RCMs with future climate data input into the hydrological models to simulate future groundwater recharge. An expert consultation workshop was organized to identify the adaptation options for managing groundwater recharge in the four cities.

The results of the study show that all four cities are expected to be warmer in the future. The highest increase $\left(2.6^{\circ} \mathrm{C}\right)$ in maximum temperature is expected for Lahore whereas the highest increase $\left(3.1^{\circ} \mathrm{C}\right)$ in minimum temperature is expected for Bandung under RCP8.5 scenarios by 2100 . However, variability in rainfall is expected in all cities. HCMC and Bandung are expected to receive less rainfall in the future and Lahore and Bangkok are expected to receive more. The recharge modelling study shows that climate change is expected to decrease groundwater recharge in HCMC and Bandung and increase it in the other two cities of Bangkok and Lahore.

Various adaptation options were identified to reduce the vulnerability of groundwater to climate change in all four cities. These adaptation options are categorized into structural measures such as rainwater harvesting and artificial recharge, and non-structural measures such as groundwater regulations and monitoring. The results of this study will be very helpful for groundwater managers in each city. However, a detailed socio-economic and environmental impact analysis is recommended to consider all adaptation options for implementation.

\section{ACKNOWLEDGEMENTS}

We are grateful to several researchers, government officials, and non-governmental organizations who participated in this project directly and indirectly by providing valuable time, experiences, expertise, and datasets, including taking part in the workshops and e-consultations. Special thanks are extended to Dr. Jariya Boonjawat, [Advisor, Atmospheric Research Group, Southeast Asia START Regional Center, Chulalongkorn University and APN Scientific Planning Group Member for Thailand], Dr. Jayakumar Ramasamy [Chief of Natural Science Sector, UNESCO, Bangkok Office], Dr. Winai Chaowiwat from Hydro and Agro Informatics Institute, Thailand, and Dr. Madan Lal Shrestha [Member, Scientific Planning Group, Asia-Pacific Network for Global Change Research (APN) and Academician, Nepal Academy of Science and Technology (NAST)] for their valuable contributions to the workshop.

\section{REFERENCES}

Arnold, J. G., Srinivasan, R., Muttiah, R. S., \& Williams, J. R. (1998). Large area hydrologic modeling and assessment part I: model development 1. JAWRA Journal of the American Water Resources Association, 34(1), 73-89.

Arnold, J. G., Moriasi, D. N., Gassman, P. W., Abbaspour, K. C., White, M. J., Srinivasan, R., \& Kannan, N. (2012). SWAT: Model use, calibration, and validation. Transactions of the ASABE, 55(4), 1491-1508.

Basharat, M. (2015). Groundwater Environment in Lahore City, Pakistan. Shrestha S., Pandey V. P., Shivakoti, B. R., \& Thatikonda, S. (Eds.) Groundwater Environment in Asian Cities: Concepts, Methods and Case Studies; Elsevier

Batelaan, O., \& De Smedt, F. (2001). WetSpass: a flexible, GIS based, distributed recharge methodology for regional groundwater modelling. IAHS Publ. 269, 11-18.

Collin, M. L., \& Melloul, A. J. (2003). Assessing groundwater vulnerability to pollution to promote sustainable urban and rural development. Journal of Cleaner Production, 11(7), 727-736.

Hiscock, K., Sparkes, R., \& Hodgson, A. (2012). Evaluation of future climate change impacts on European groundwater resources. In Treidel, H., Martin-Bordes, J. L., \& Gurdak, J. J. (Eds.), Climate Change Effects on Groundwater Resources: A Global Synthesis of Findings and Recommendations (414). Taylor \& Francis.

Jyrkama, M. I., \& Sykes, J. F. (2007). The impact of climate change on spatially varying groundwater recharge in the Grand River watershed (Ontario). Journal of Hydrology, 338(3-4), 237-250.

Liu, H. H. (2011). Impact of climate change on groundwater recharge in dry areas: An ecohydrology approach. Journal of Hydrology, 407(1-4), 175-183.

Masui, T., Matsumoto, K., Hijioka, Y., Kinoshita, T., Nozawa, T., Ishiwatari, S., ... \& Kainuma, M. (2011). An emission pathway for stabilization at $6 \mathrm{Wm}-2$ radiative forcing. Climatic change, 109(1-2), 59.

McSweeney, C. F., Jones, R. G., Lee, R. W., \& Rowell, D. P. (2015). Selecting CMIP5 GCMs for downscaling over multiple regions. Climate Dynamics, 44(11-12), 3237-3260.

Morris, B. L., Lawrence, A. R., Chilton, P. J., Adams, B., Calow, R., \& Klinck, B.A. (2003). Groundwater and its susceptibility to degradation: A global assessment of the problems and options for management. Early Warning and Assessment Report Series, RS, 03-3. United Nations Environment Programme, Nairobi, Kenya.

Ng, G.-H. C., McLaughlin, D., Entekhabi, D., \& Scanlon, B. R. (2010). Probabilistic analysis of the effects of climate change on groundwater recharge. Water Resources Research, 46(7).

Okkonen, J., \& Kløve, B. (2010). A conceptual and statis- 
tical approach for the analysis of climate impact on ground water table fluctuation patterns in cold conditions. Journal of Hydrology, 388(1-2), 1-12.

Riahi, K., Rao, S., Krey, V., Cho, C., Chirkov, V., Fischer, G., ... Rafaj, P. (2011). RCP 8.5-A scenario of comparatively high greenhouse gas emissions. Climatic Change, 109(1), 33. http://doi.org/10.1007/s10584011-0149-y

Shrestha, S., Pandey, V. P., Thatikonda, S., \& Shivakoti, B. R. (Eds.). (2016). Groundwater environment in Asian cities: concepts, methods and case studies. Butterworth-Heinemann.

Taylor, R. G., Scanlon, B., Döll, P., Rodell, M., Van Beek, R., Wada, Y., ... \& Konikow, L. (2013). Ground water and climate change. Nature Climate Change, 3(4), 322.

Tirtomihardjo, H. (2015). Groundwater environment in Bandung, Indonesia. In Shrestha, S., Pandey, V. P., Thatikonda, S., \& Shivakoti, B. R. (Eds.). (2016). Groundwater environment in Asian cities: concepts, methods and case studies (193-228). Butterworth-Heinemann.

Van Vuuren, D. P., Edmonds, J., Kainuma, M., Riahi, K., Thomson, A., Hibbard, K., ... \& Masui, T. (2011). The representative concentration pathways: an overview. Climatic Change, 109(1-2), 5.

Vuong, B. T., Long, P.N., \& Nam, L. H. (2015). Groundwater environment in Ho Chi Minh, Vietnam. In Shrestha, S., Pandey, V. P., Thatikonda, S., \& Shivakoti, B. R. (Eds.). (2016). Groundwater environment in Asian cities: concepts, methods and case studies. Butterworth-Heinemann. 